\title{
Synthesis Polymer Matrix Composite Epoxy-FeNdB-Mn for Radar Absorbing Material Application
}

\author{
Gibran Juniansyah \\ Metallurgical Engineering, Universitas \\ Jenderal Achmad Yani, Bandung, \\ Indonesia \\ gibrannjuniansyah@gmail.com \\ Sri Mulyati Lathifah \\ 1Metallurgical Engineering, Universitas \\ Jenderal Achmad Yani, Bandung, \\ Indonesia \\ endangcn@gmail.com \\ Djoko Hadi Prajitno \\ PSTNT-BATAN, Jl. Tamansari 71 \\ Bandung 40123, Indonesia \\ hjoko60@gmail.com
}

In recent years, applications using electromagnetic wave technology have grown rapidly. One of them is in the military field, the wave-absorbing material used to avoid detection such as aircraft, ships, or tanks requires a super thin absorbent material which has extraordinary absorption. One of the criteria for a wave absorbing material is a soft magnet and has a high Reflection Loss (RL). This research aims to see the effect of the addition of FeNdB and Mn on the synthesis of Polymer Matrix Composite (PMC) as a wave-absorbing material. The FeNdB milling process and Mechanical Alloying (MA) with Mn were carried out using a Planetary Ball Mill (PBM) at a speed of 1000 rpm for 60 minutes. Synthesis of PMC by varying the composition of epoxy resin with magnetic powder 95: 5; 90:10; 85: 5. Based on the characterization results, the optimum $R L$ was obtained at a composition of 85: 5 with a value of $-22.40 \mathrm{~dB}$ at a frequency of $10.40 \mathrm{GHz}$ and the magnetic properties after the addition of $\mathrm{Mn}$ were obtained HcJ $0.116 \mathrm{kOe}$ and $\mathrm{Br} 0.41 \mathrm{kG}$. PMC hardness increased with the increase of powder in the sample with the highest value of 29.2 HD Shore D and the adhesion decreased with the addition of powder in the sample with the lowest value of 1 $M P a$.

Keywords: Polymer Matrix Composite, Radar Absorber Material, FeNdB, Reflection Loss.

\section{INTRODUCTION}

In recent years, applications using electromagnetic wave technology have grown rapidly [1]. Radar is a modern detection tool that uses radio waves to detect enemy movements. The advantage of using radar as a detection system is that it actively monitors the target energy from the waves it emits [2]. In the military defense, radar is widely used to detect enemy targets. To anticipate this, stealth technology has been developed for aircraft and warships. The efficiency of stealth technology depends on how much EM (Electro Magnetic) energy is reflected back to the receiver by the target. This is called the RCS (Radar Cross Section). So that the target is not detected, the RCS value must be as small as possible [3].

To reduce the RCS value, four anti-radar designs were developed, namely shaping, Radar Absorbing Material (RAM), passive cancellation and active cancellation. The shaping method is used to reduce the radar signal that is reflected back to the receiver. Shaping is used by designing the shape or geometry of the antiradar object at an angle, so that the cross-sectional area can catch is getting smaller. With an angled design, the received radar waves will be reflected randomly in another direction so that they are not recaptured by the receiver. While the second method is to use a radar wave absorbing material called RAM (Radar Absorbing Material). This method is based on 2 absorption principles consisting of magnetic and dielectric aspects. With these 2 aspects, it is hoped that the received radar waves can be completely absorbed by the anti-radar material. Then the third method, namely passive cancellation, is an anti-radar method by coating the dielectric material. This method is designed to modify the surface impedance so that the returning radar signal is scattered everywhere. The fourth method is active cancellation, which is a method used to detect incoming radar signals and then amplify the return signal. So the reflected signal has a proportional amplitude and a phase opposite to the incident signal. As a result, the reflected signal is scattered and crashes into other incoming signals [4]. 


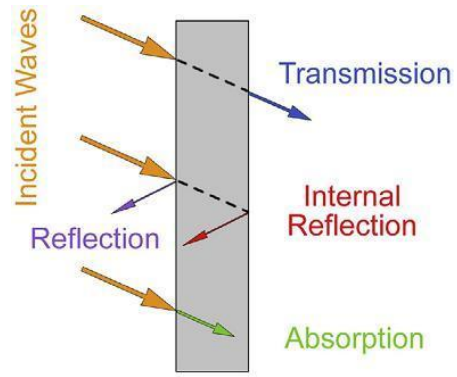

Figure 1. Method of decreases RCS [5].

There are two types of magnets currently used, namely non-permanent (remanent) magnets that depend on electric fields to produce magnetic fields such as electromagnetic magnets, and permanent magnets that do not require external forces to form magnetic fields such as Neodymium magnets, and Samarium magnets. The choice of permanent magnets is preferred as a constituent material for RAS (Radar Absorber Structure), RAM (Radar Absorber Material), and RAC (Radar Absorber Coating) concerning the effectiveness and mobility of the permanent magnet itself which does not depend on external forces. Compared with conventional permanent magnets, permanent magnets containing rare earth metals have better magnetic properties, namely coercivity, remanence, and the maximum value of product energy.

Neodymium-Iron-Boron $(\mathrm{NdFeB})$ permanent magnets have always attracted a lot of attention since their discovery in the 1980s because of their excellent performance [6]. So that the magnetic technology to produce high quality magnetic materials is largely determined by the material process technology as well. For this reason, it is necessary to research the manufacture of this magnet because $\mathrm{NdFeB}$ magnets have a very high tensile force between the poles.

The method used in this research is MA, which then combines the powder with epoxy-based paint to form a PMC and ends with a coating on the substrate to produce optimum RL. From the things that have been stated above, this study takes the theme "Synthesis Polymer Matrix Composite Epoxy-FeNdB-Mn for Radar Absorbing Material Application".

\section{EXPERIMENTAL AND METHOD}

\subsection{Materials and Instruments}

This study used materials consisting of FeNdB (as casted scrap), Mn powder, and epoxy resin (PT. Brataco) as a matrix.

The equipment used in this study consisted of the Mettler Toledo AL204 Analytical scale to weigh the materials according to the composition in Table 1, PBM PQ-N2 for powder mechanical alloying processes, Durometer Shore D to obtain PMC hardness values which refer to ASTM D 2240 standard, Elcometer 106 for measuring coating adhesion according to the ASTM D 4541 standard, Permagraph $\mathrm{C}$ for measuring magnetic characteristics, and AV3672A-S Vector Network Analyzer for measuring the reflection loss of the waveabsorbing layer.

Table 1. Composition of PMC.

\begin{tabular}{c|c|c|c}
\hline \multicolumn{2}{c|}{ Resin Epoxy } & \multicolumn{2}{c}{ Magnetic powder } \\
\hline $95 \% \mathrm{wt}$ & $95 \mathrm{gr}$ & $5 \% \mathrm{wt}$ & $5 \mathrm{gr}$ \\
\hline $90 \% \mathrm{wt}$ & $45 \mathrm{gr}$ & $10 \% \mathrm{wt}$ & $5 \mathrm{gr}$ \\
\hline $85 \% \mathrm{wt}$ & $28.33 \mathrm{gr}$ & $15 \% \mathrm{wt}$ & $5 \mathrm{gr}$ \\
\hline$\Sigma$ & $168.33 \mathrm{gr}$ & & $15 \mathrm{gr}$ \\
\hline
\end{tabular}

\subsection{Method and Procedure}

PMC synthesis is made as a wave-absorbing layer using epoxy resin as a matrix and FeNdB powder that has been doped with manganese as a magnetic material, the variations in the ratio of composition of epoxy resin and magnetic powder are shown in Table 1. FeNdB milling and mixing with Mn doping were carried out using PBM at a speed of $1000 \mathrm{rpm}$ for 60 minutes, the vials used in PBM were two with a composition of 1:10. The method used is dry milling with SS 304 ball mill material. 
After the mixing process, two different processes were carried out to obtain the desired characterization data. The first process is making pellet samples. The powder was compaction with an emphasis of $25 \mathrm{MPa}$ with the final dimensions D: $11 \mathrm{~mm}$, th: $5 \mathrm{~mm}$, then the sintering process was carried out for 3 hours at a temperature of $1000^{\circ} \mathrm{C}$ for Permagraph, XRD, SEM-EDS characterization.

The second process is the manufacture of PMC for the coating process. The powder that has been mixed is then homogenized into epoxy resin with a stirring time of 15 minutes. After the homogenization process is complete, PMC is applied to the substrate surface (Al 2024) which has been surface preparation with 240 and 400 mesh sandpaper. The coating application process is carried out in a conventional single layer using brush number 3. The coated substrate is then characterized using VNA with a frequency range of $8-12 \mathrm{GHz}$, hardness with Durometer Shore D, and Adhesive with Elcometer model 106.

\section{RESULT AND DISCUSSION}

Results data obtained from the research process get results in the form of graphic values and the results of tests conducted during the research process. The testing process carried out on test specimens is SEM-EDS, XRD, hardness, adhesive, permagraph, and VNA. Then rsult of SEM-EDS with 5000x and 10000x magnification can be seen in Figure 2.
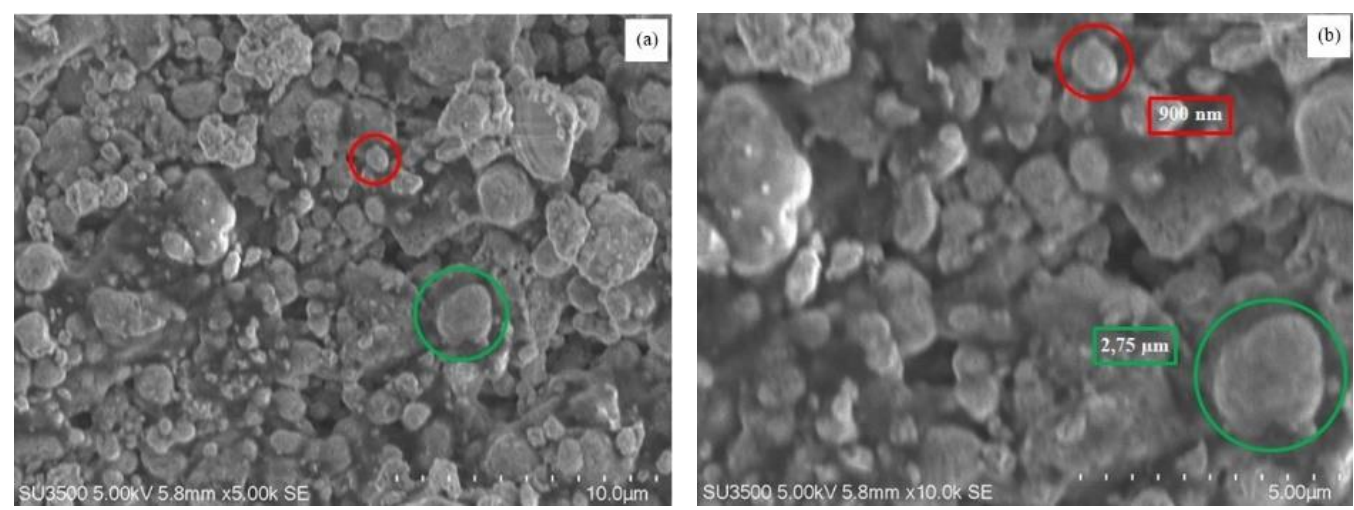

Figure 2. SEM of FeNdB+Mn (a) 5000x; (b) 10000x magnification.

From the test results with a magnification of $10000 \mathrm{x}$, measurements were made of the smallest and largest items, respectively, $0.9 \mu \mathrm{m}$ and $2.75 \mu \mathrm{m}$. SEM observations also check for porosity in the sample. This is due to the enlargement of the grain during the sintering process at a temperature of $1000^{\circ} \mathrm{C}$ so that the grain size becomes bigger and the more cavities that occur in the porosity section ${ }^{[7]}$. the sample.

Energy Dispersive Spectroscopy (EDS) to determine the \%weight and \%atomic elements contained in

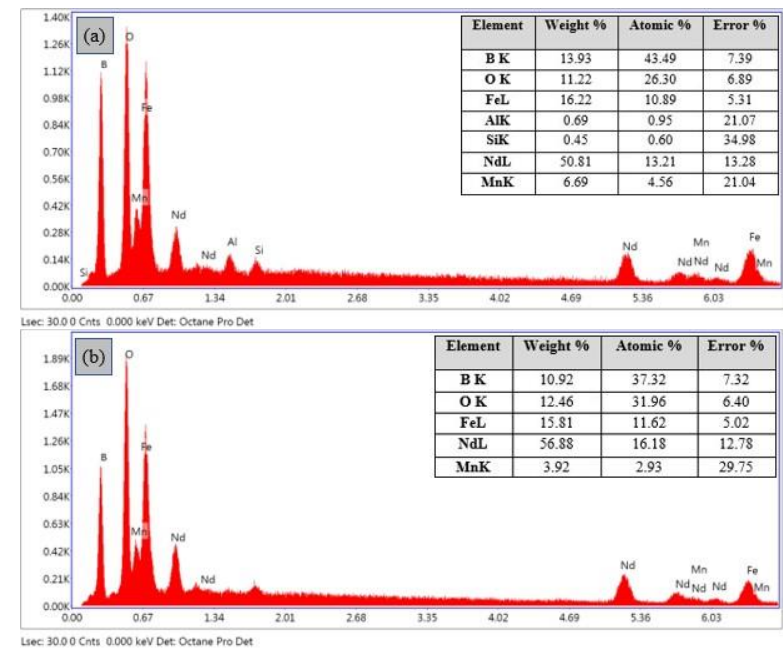

Figure 3. EDS (a) FeNdB; (b) $\mathrm{FeNdB}+\mathrm{Mn}$.

In Figure 3 (a), Nd elements have the greatest composition, namely 50.81\% weight, Fe and B elements, namely $16.22 \%$ weight and $13.93 \%$ weight. While the Mn doping element that was initially added was only $2.5 \%$, the EDS result became $6.69 \%$ weight, this could be caused by an error in the tool because it was seen 
that the\% error result for Mn element was $21.04 \%$.

The presence of $\mathrm{Al}$ and $\mathrm{Si}$ in the sample is probably caused by sanding before the test so that the sandpaper material enters the porosity of the sample, it can be seen that the Al and Si levels are very small, namely $0.69 \%$ weight and $0.45 \%$ weight.

In the second EDS test, namely looking at the constraints on the selected item, $\mathrm{Nd}$ has the largest content in the sample, namely $56.88 \%$ weight, while Fe and B are $15.81 \%$ weight and $10.92 \%$ weight. The addition of the $\mathrm{Mn}$ element with the initial plan was $2.5 \%$, increasing to $3.92 \%$ weight in the test results. This can be caused by errors in the tool so that the $\%$ error value of the element is quite large, namely $29.75 \%$.
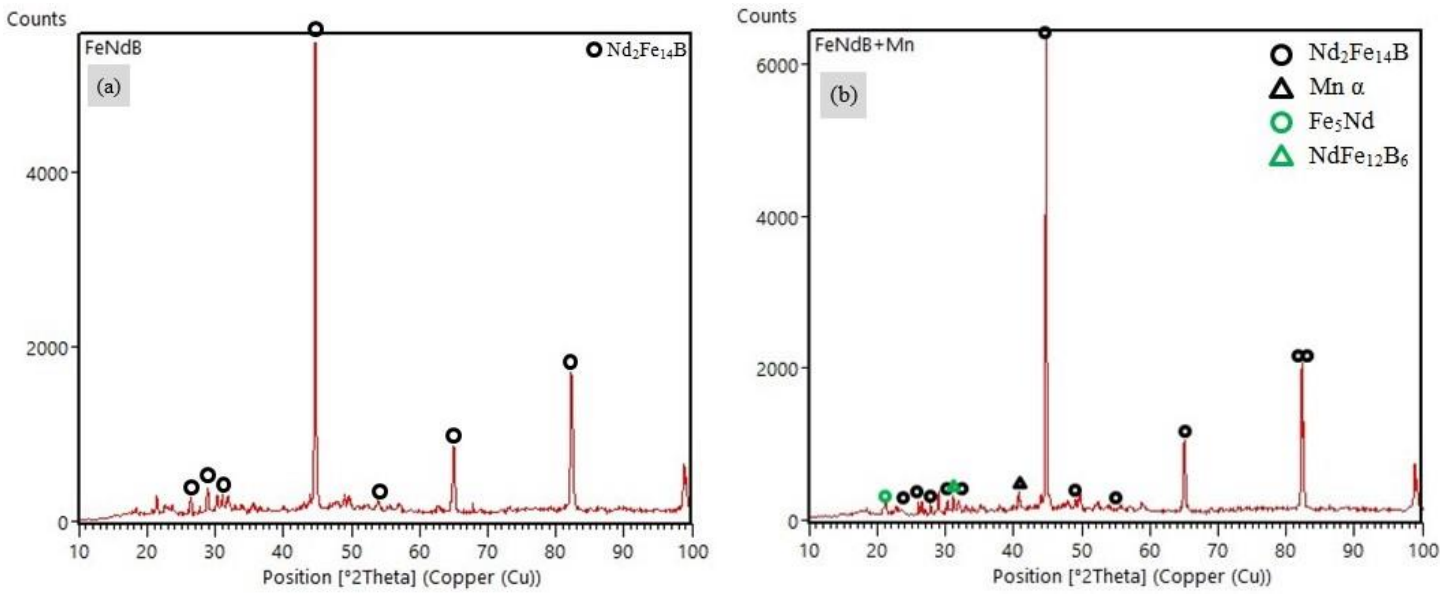

Figure 4. XRD (a) FeNdB; (b) FeNdB+Mn.

XRD analysis of the crystal structures of FeNdB and FeNdB with the addition of the element Mn aims to observe the phases formed in the test sample after sintering at a temperature of $1000^{\circ} \mathrm{C}$. the samples tested were in the form of pellets. The analysis is carried out using the highscore plus and origin applications.

In the sample without the addition of $\mathrm{Mn}$, it was found that the compound formed was $\mathrm{Nd}_{2} \mathrm{Fe}_{14} \mathrm{~B}^{[8]}$. The sample with the addition of Mn shows the presence of Manganese-alpha, and the compound formed is similar to the sample without the addition of $\mathrm{Mn}$, which is dominated by the $\mathrm{Nd}_{2} \mathrm{Fe}_{14} \mathrm{~B}$ compound.

Hardness testing was carried out using the Durometer Shore D test tool concerning the ASTM 2240 standard. The hardness value obtained by the sample with the ratio of epoxy resin and magnetic powder can be seen in Figure 5.

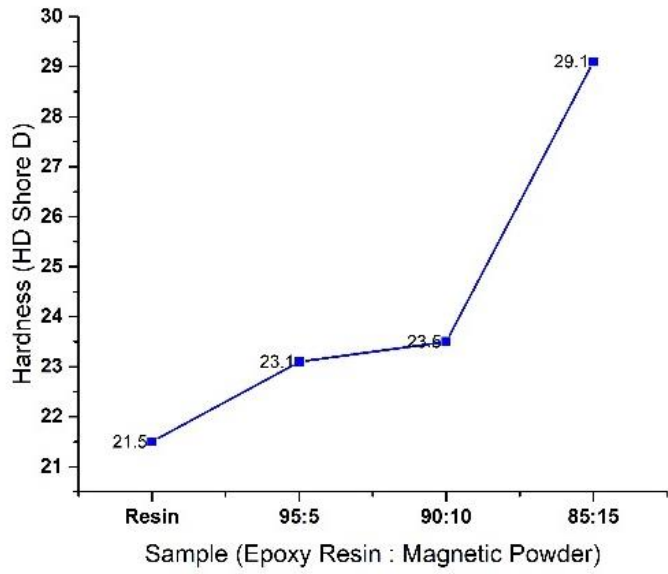

Figure 5. Hardness Durometer Shore D.

The hardness value increases with the addition of magnetic powder in the sample, the values obtained with the ratio of epoxy resin and powder 100: 0, 95: 5, 90:10, 85:15 are $21.5 \mathrm{HD}$, respectively; $23.1 \mathrm{HD} ; 25.5$ $\mathrm{HD} ; 29.1 \mathrm{HD}$.

The adhesive test was carried out using the Elcometer 106 pull-off adhesion tester which refers to the ASTM D4541 standard. The results of the adhesive test can be seen in Figure 6. 


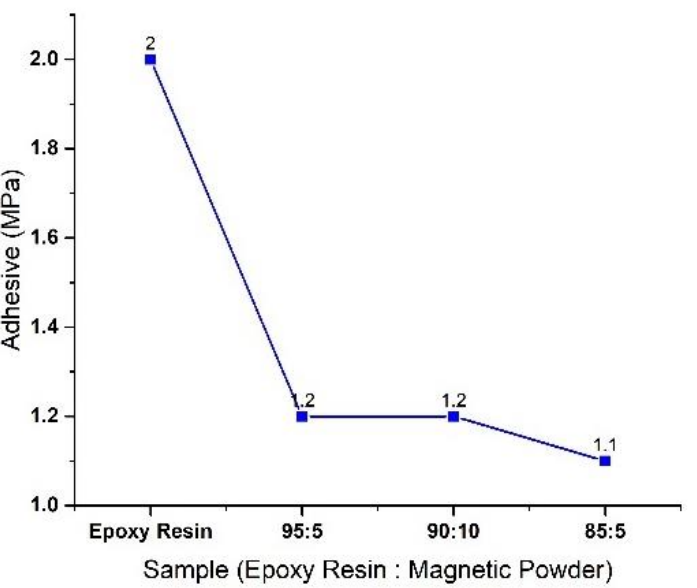

Figure 6. Adhesive of PMC.

From the test results that the increase in powder composition, the lower the adhesive value due to the presence of powder on the substrate surface, causing the epoxy resin not to adhere completely to the surface of the substrate.

the results of the adhesive test on samples with a composition of 100: 0 epoxy resin and magnetic powder; 95:5; 90:10; 85:15 respectively, namely 1.2 $\mathrm{MPa}$; 1.2 $\mathrm{MPa}, 1.2 \mathrm{MPa} ; 1 \mathrm{MPa}$

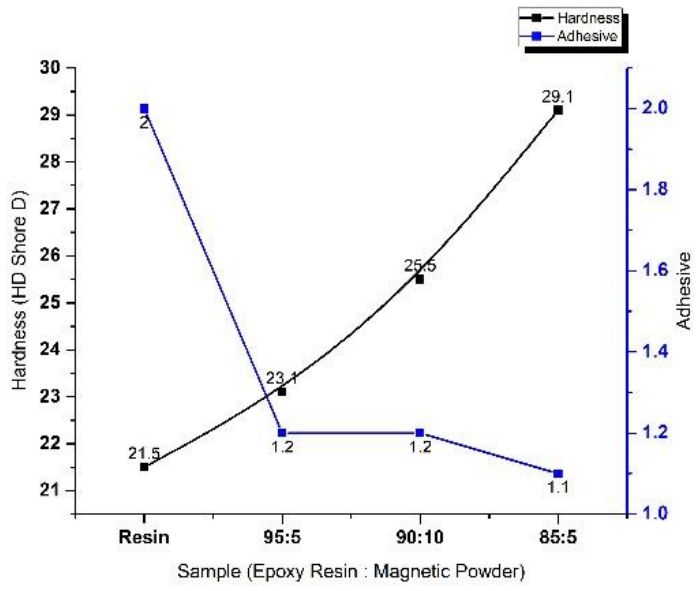

Figure 7. Comparison Hardness and Adhesive.

The permagraph test results are in the form of a hysterical curve which can be seen in Figure 7.

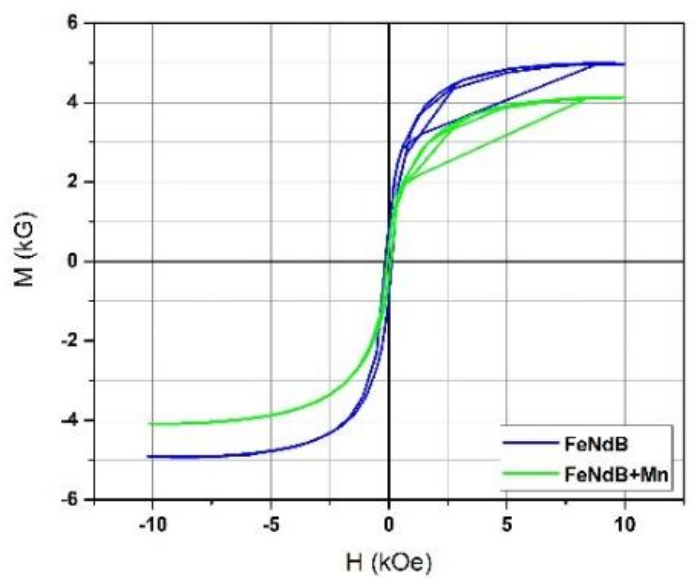

Figure 8. Hysteresis Loop of FeNdB. 
Table 2. Magnet Characterization.

\begin{tabular}{c|c|c|c}
\hline Sample & $\begin{array}{c}\text { Br Remanence } \\
(\mathbf{k G})\end{array}$ & $\begin{array}{c}\text { HcJ Coercivity } \\
(\mathbf{k O e})\end{array}$ & $\begin{array}{c}\text { MS Saturation } \\
(\mathbf{k G})\end{array}$ \\
\hline $\mathrm{FeNdB}$ & 0,83 & 0,072 & 0,57 \\
\hline $\mathrm{FeNdB}+\mathrm{Mn}$ & 0,41 & 0,116 & 2,86 \\
\hline
\end{tabular}

It can be seen in Figure 7 that the addition of Mn doping makes the hysterical curve remain in the soft magnetic condition. From Table 2 it is known that the addition of $\mathrm{Mn}$ increases the coercivity of $0.116 \mathrm{kOe}$, while the FeNdB sample without doping is $0.072 \mathrm{kOe}$, but with a coercivity value below $0.2 \mathrm{kOe}$, the magnet is soft magnet ${ }^{[9]}$. The nature of soft magnets is one of the requirements for a radar absorber material.

The test results showed that the remanence value of the FeNdB sample and the addition of Mn was 0.83 $\mathrm{kG}$ and $0.41 \mathrm{kG}$, respectively. Measurement errors can occur due to testing, for example, errors in filling in the initial data or cracks in the sample. Defects in the sample will affect coercivity, this has been explained by William D. Callister in his book who said that the coercivity value is sensitive to structural variables, defects in the material will cause an increase in the coercivity value. William D. Callister in his book also states that the saturation or magnetization value is influenced by the composition of the material ${ }^{[10]}$.

VNA testing is carried out in the $\mathrm{x}$-band range or at a frequency of 8-12 GHz. X-band is a frequency that is widely applied for the use of military grade radar tracking and weather satellites. In the test results, a comparison is made between the four samples which can be seen in Figure 8.

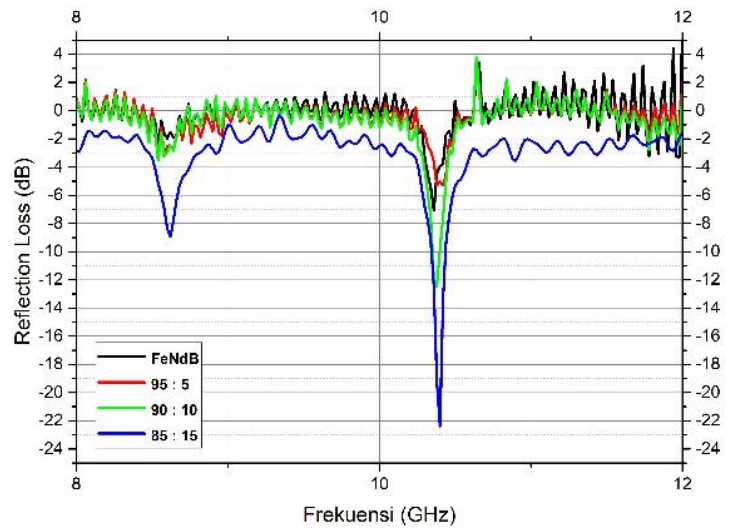

Figure 9. VNA of PMC.

Table 3. Result of VNA.

\begin{tabular}{c|c|c|c|c}
\hline $\begin{array}{c}\text { Sample } \\
\text { (Epoxy:powder) }\end{array}$ & $\begin{array}{c}\text { Reflection Loss } \\
(\mathbf{d B})\end{array}$ & $\begin{array}{c}\text { Frequency } \\
(\mathbf{G H z})\end{array}$ & $\begin{array}{c}\text { Absorption } \\
\text { coefficient, } \boldsymbol{\Gamma}\end{array}$ & $\begin{array}{c}\text { Absorption } \\
\text { percentage } \\
(\%)\end{array}$ \\
\hline $\begin{array}{c}\mathbf{\%}: 5 \\
(\text { doped Mn) }\end{array}$ & $-5,06$ & 10,40 & 0,5584 & 44,16 \\
\hline $\begin{array}{c}90: 10 \\
(\text { without doped Mn) }\end{array}$ & $-7,95$ & 10,36 & 0,4216 & 57,84 \\
\hline $\begin{array}{c}90: 10 \\
(\text { doped Mn) }\end{array}$ & $-12,36$ & 10,38 & 0,2409 & 75,91 \\
\hline $85: 15$ & $-22,40$ & 10,40 & 0,0758 & 92,42 \\
\hline
\end{tabular}

$$
\Gamma=10^{\mathrm{RL} / 20}
$$

$\%$ Absorpsion $=100(1-\Gamma)$ 
From the test results obtained the highest absorption value in the sample with a ratio of epoxy resin and magnetic powder $85: 15$, with a percentage of absorption reaching $92.42 \%$. This means that only $7.58 \%$ of the energy is reflected.

The reflection coefficient $\Gamma$ is the ratio of the reflected waves back to the incident waves. If the reflection coefficient has a value of 0 , it can be concluded that the input impedance (I) is matched with the external impedance or that the entire wave is successfully absorbed by the material. The average coefficient is 0.3241 .

The addition of Mn was proven to make the reflection loss value better with the sample value without doping -7.95 dB and after $-12.36 \mathrm{~dB}$ doping. It can be seen in figure 10.

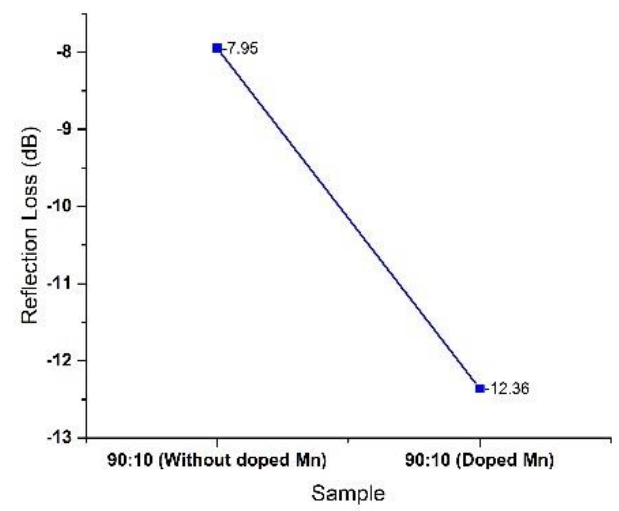

Figure 10. VNA Comparison.

From the results of these tests, it can be said that the study of polymer matrix composite synthesis with $\mathrm{FeNdB}$ and Mn doping has proven that there is an increase in reflection loss along with the increase in powder in the ratio of epoxy resin and powder.

\section{CONCLUSION}

From the test results with a magnification of $10000 \mathrm{x}$, measurements were made of the smallest and largest items, respectively, $0.9 \mu \mathrm{m}$ and $2.75 \mu \mathrm{m}$. In the sample without the addition of $\mathrm{Mn}$, it was found that the compound formed was $\mathrm{Nd}_{2} \mathrm{Fe}_{14} \mathrm{~B}^{[8]}$. The sample with the addition of $\mathrm{Mn}$ shows the presence of Manganesealpha, and the compound formed is similar to the sample without the addition of $\mathrm{Mn}$, which is dominated by the $\mathrm{Nd}_{2} \mathrm{Fe}_{14} \mathrm{~B}$ compound. The hardness value increases with the addition of magnetic powder in the sample, the values obtained with the ratio of epoxy resin and powder 100: 0, 95: 5, 90:10, 85:15 are 21.5 HD, respectively; $23.1 \mathrm{HD} ; 25.5 \mathrm{HD} ; 29.1 \mathrm{HD}$. From the test results that the increase in powder composition, the results of the adhesive test on samples with a composition of 100: 0 epoxy resin and magnetic powder; 95: 5; 90:10; 85:15 respectively, namely 1.2 MPa; 1.2 MPa, 1.2 MPa; $1 \mathrm{Mpa}$. The addition of Mn increases the coercivity of $0.116 \mathrm{kOe}$, while the FeNdB sample without doping is $0.072 \mathrm{kOe}$, but with a coercivity value below $0.2 \mathrm{kOe}$, the magnet is soft magnet ${ }^{[9]}$. The maximum Reflection Loss values obtained by the sample with the ratio of epoxy resin and magnetic powder 95: 5, 90:10, 85:15 are $-5.06 \mathrm{~dB},-12.36 \mathrm{~dB}$, and -22.40 , respectively. $-10.36 \mathrm{GHz}, 10.40 \mathrm{GHz}, 10.38 \mathrm{GHz}$, and $10.40 \mathrm{GHz}$ respectively. The addition of Mn was proven to make the reflection loss value better with the sample value without doping $-7.95 \mathrm{~dB}$ and after $-12.36 \mathrm{~dB}$ doping.

\section{ACKNOWLEDGEMENT}

The author would like to thank PSTNT-BATAN for providing materials, tools, and research sites as well as Metallurgical Engineering UNJANI and all parties who have helped the author in completing this research.

\section{REFERENCES}

[1] AN, Y.J.,et al. "Characteristic Evaluation of Microwafe Absorbers Using Dielectric and Magnetic Composite Material”. Journal od Ceramic Processing Research Vol.9 No.4 pp.430-436. 2011.

[2] I. O. P. C. SERIES and M. SCIENCE, "Effect of Particle Size Distribution on the Preparation of Bonded $\mathrm{NdFeB}$ Permanent Magnet Effect of Particle Size Distribution on the Preparation of Bonded NdFeB 
Permanent Magnet,” pp. 1-7, 2019, doi: 10.1088/1757-899X/622/1/012012.

[3] P. SAVILLE, "Review of Radar Absorbing Materials Defence R \& D Canada - Atlantic," Def. Res. Dev. Canada. January, p. 62, 2005.

[4] MUJAMILAH, et al. Penghalusan Serbuk dan Efeknya Pada Fasa dan Sifat Magnetik Sistem Magnet Permanen Berbasis $\mathrm{Nd}_{2} \mathrm{Fe}_{14} \mathrm{~B}$, Jurnal Sains Materi Indonesia. 7 (2019), pp. 21-24

[5] P. AMBARDI and Y. M. SAIT, "Efek Penambahan Partikel Barium Heksaferrit $\left(\mathrm{BaFe}_{12} \mathrm{O}_{19}\right)$, Neodybium (NdFeB) dan Grafit (C) terhadap Kemampuan Penyerapan Gelombang Radar pada Cat Berbasis Polyurethane Fr 2 / 55 Top Coat,”. 2015.

[6] Y. E. GUNANTO, L. CAHYADI, and W. A. ADI, "Effect of Mn and Ti sub s titution on the reflection loss," vol. 19, pp. 2-8, 2016, doi: 10.1063/1.4945477.

[7] T. KRISTIANTORO, N. SUDRAJAT, and W. BUDIAWAN, "Pembuatan dan Karakterisasi Magnet Bonded NdFeB dengan Teknik Green Compact," pp. 9-11, 2013.

[8] C. KURNIAWAN and P. SEBAYANG, "PELAPISAN Ni PADA MAGNET BONDED Nd-Fe-B DENGAN METODE," no. July, 2012.

[9] S. VIRDHIAN, D. H. PRAYITNO, S. JAMILAH, B. BESAR, and K. PERINDUSTRIAN, "NdFeB ALLOYS MAKING FOR PERMANENT MAGNET RAW MATERIALS APPLICATIONS,” vol. 38, no. 2, 2016.

[10] L. LI et al., "Big Area Additive Manufacturing of High Performance Bonded NdFeB Magnets," Nat. Publ. Gr., no. October, pp. 1-7, 2016, doi: 10.1038/srep36212.

[11] RUSTAMAJI, \& DJAELANI, E. Radar Jamming Suatu Konsep Rancang Bangun. 2011. Seminar Radar Nasional. ISSN 1979-2921.

[12] SRI BIMO PRATOMO, YONGJIN KIM, DJOKO PRAJITNO. "Effects of Water Quenching Before Hydrogenation,Disproportionation, Desoption and Recombination Process on Magnetic Properties of Nd-Fe-B Powder”. 2016. International Journal of Technology. 7(3):471.

[13] ELECTRANS, et al. Ultrasonic Radar Navigation By Using UltrasonicSensor. 2017. Journal of Emerging Technologies and Innovative Research (JETIR), 4(7), 138-140.

[14] C. K. YUZCELIK, D. JENN, and R. ADLER, "Radar Absorbing Material Design". September, 2003.

[15] FADHALLAH, ES A GHANIM, dkk. Protoype Material Penyerap Gelombang Radar dari Komposit Polimer - Polivinil Alkohol. 2012. UT - Aquatic Product Technology [1227].

[16] HALLIDAY, DAVID, et al. Fundamentals of Physics. 1960. United States.

[17] EFAN AHMAD. Polimer. Jurusan Teknik Mesin Universitas Mudamadiyah Jember. 2010. Jember.

[18] D. I. BOWER, An Introduction to Polymer Physics. Cambridge University Press, 2002.

[19] A.F. RIKSON, et al. Polimer: Ilmu Material. USU. USU Press. 2017. Medan, Indonesia. 